\title{
EVOLUÇÃO DO PERFIL INTERNO DOS ALTOS FORNOS BRASILEIROS DO SÉCULO XIX *
}

\section{Resumo}

Paulo Eduardo Martins Araujo ${ }^{1}$ Jefferson de Lima Picanço ${ }^{2}$ Gabriel Faria ${ }^{3}$ Marcelo Knörich Zuffo ${ }^{4}$ Marcello Balzani ${ }^{5}$ Luca Rossato 6

Daniele Felice Sasso ${ }^{7}$

Fernando José Gomes Landgraf ${ }^{8}$

Pesquisadores da Universidade de Ferrara (Itália) e da Escola Politécnica da USP escanearam o interior e o exterior dos altos-fornos da Fábrica de Ferro de São João do Ipanema, um dos poucos remanescentes no continente americano da linha técnica de produção de ferro-gusa que remonta ao século $X V$, e que são os fornos a carvão vegetal em alvenaria de rocha lavrada. Este empreendimento siderúrgico operou no Brasil entre os anos 1810 e 1926. O escaneamento registrou o último estágio das transformações pelas quais passaram os perfis do vazio interior destes altos-fornos, originalmente edificados em 1817, pelo engenheiro Frederico Varnhagen. Este trabalho apresenta a evolução dos perfis dos altos-fornos com base numa surpreendentemente rica literatura técnica brasileira, a qual registra, com descrições e desenhos, as alterações ocorridas nos perfis ao longo dos séculos XIX e início do XX. Os perfis foram modificados visando melhorar a produtividade dos equipamentos, aferida por exame sistemático do indicador até hoje utilizado pela siderurgia, a produção em toneladas de ferro-gusa produzido por dia. As relações entre perfil do alto-forno, consumo de combustível e produtividade ainda estavam em construção na literatura europeia especializada do século XIX, o que indica que os diretores que operaram as transformações em Ipanema estavam familiarizados com os procedimentos técnicos e científicos próprios desta engenharia.

Palavras-chave: História da siderurgia; Altos-fornos; Fábrica de ferro de Ipanema.

\section{INTERNAL PROFILE EVOLUTION OF XIX CENTURY BRAZILIAN BLAST FURNACES}

\section{Abstract}

Researchers from the University of Ferrara (Italy) and from the Polytechnic School of the University of São Paulo scanned the interior and the exterior of the blast furnaces of Fabrica de Ferro de São João do Ipanema. They are three of the few remaining XIX century charcoal blast furnaces in the American Continent. It operated between 1810 and 1926. The scans registered the last transformation stage of the internal profile of these blast furnaces, built in 1817 by the German engineer Friedrich Varnhagen. This paper presents the evolution of the internal profiles, based on a surprisingly rich technical literature that registers, with descriptions and drawings, the changes that occurred during the XIX and early XX centuries. The profiles were modified to improve the productivity of the furnaces, based on the performance indicator used until today, the pig iron weight produced per day. The relations between the internal profile, coal consumption and productivity were yet in construction, in the specialized European literature of the XIX century, which indicates that the enterprise directors were aware of the technical and scientific procedures of the day.

Keywords: ironmaking history; blast furnace; internal profile; Ipanema Iron Factory. 
1 História, Mestrado, Doutorando, PEHCT, Instituto de Geociências da Unicamp, Campinas, SP

2 Professor do Instituto de Geociências da Unicamp, Campinas, SP.

3 Estudante de Graduação, Departamento de Engenharia Metalúrgica e de Materiais, Escola Politécnica, USP, São Paulo, SP

4 Professor da Escola Politécnica da USP, Diretor do Centro Interdisciplinar em Tecnologias interativas (Citi), Escola Politécnica, USP.

5 Professor Associado, Departamento de Arquitetura, Universidade de Ferrara. Diretor do Centro de Pesquisa DIAPReM, Ferrara, Itália

6 Doutor, Departamento de Arquitetura, Universidade de Ferrara. Pesquisador do Centro de Pesquisa DIAPReM, Ferrara, Itália

7 Professor contratado, Departamento de Arquitetura, Universidade de Ferrara. Pesquisador do Centro de Pesquisa DIAPReM, Ferrara, Itália

8 Engenheiro, Professor, Departamento de Engenharia Metalúrgica e de Materiais, Escola Politécnica, USP, São Paulo, SP e Presidente do Instituto de Pesquisas Tecnológicas do Estado de São Paulo, São Paulo. 


\section{INTRODUÇÃO}

A história da engenharia brasileira ao longo do século XIX tem sido abordada em algumas publicações [1,2]. Este trabalho propõe um novo olhar sobre um de seus ramos, a engenharia metalúrgica, mais especificamente a siderurgia.

A Fábrica de Ferro de Ipanema foi um empreendimento do governo central lusobrasileiro e brasileiro, iniciado logo após a chegada da família real portuguesa ao Brasil, conduzido com altos e baixos ao longo do império e encerrado na República. Atravessou mais de 100 anos sendo considerada ou como estratégica ou um grande dreno de recursos financeiros. Durante a maior parte do tempo esteve sob a tutela militar, passando para o ministério da agricultura em um de seus períodos mais ativos, entre 1878 e 1890. Teve momentos de grandes investimentos e momentos em que nem os salários eram pagos. A logística de distribuição das 100 a 300 toneladas anuais de ferro que a fábrica produzia desde o início foi considerado um grande entrave para seu sucesso. A chegada dos trilhos da Sorocabana, em 1879, entretanto, não provocou mudança significativa na demanda, pois o crescimento da malha ferroviária reduzia os custos do ferro importado para todo o mercado. A mão de obra também foi um desafio perene: operar continuamente altos fornos e forjas de refino envolve tarefas extenuantes, que a sucessiva contratação de escravos, operários alemães, austríacos e depois italianos, ao longo do século XIX, não resolveu. A matéria-prima, inicialmente considerada inexaurível, apresentou também seus problemas: foi difícil obter um suprimento confiável de carvão vegetal e o minério de ferro magnetítico talvez tenha provocado dificuldades de processo, mas não de qualidade de produto, apesar de famosas opiniões contrárias [3]. Este trabalho quer demonstrar que o conhecimento aportado via literatura e aprendizado técnico, que tem um papel muito importante na capacidade de operar um empreendimento deste porte, esteve presente ao longo da sua vida, e refletiu-se nas transformações pelas quais passaram os altos fornos de Ipanema. Quando finalmente a iniciativa privada enxergou a oportunidade de investir nesse tipo de negócio, o fez em Minas Gerais.

O trabalho se baseia na literatura produzida naquele século sobre a Fábrica de Ferro de Ipanema, nos relatórios técnicos feitos para o exército e para o governo e em artigos publicados em revistas e jornais, cotejados com a literatura mundial que the era contemporânea. Além disso, técnicas modernas de levantamento dimensional puderam gerar mais informações sobre os fornos em seu estado atual. Dentre as muitas variáveis de processo que tiveram que ser trabalhadas pelos engenheiros e técnicos daquela fábrica para produzir milhares de toneladas de barras de ferro e peças de ferro fundido, este trabalho aborda uma que foi reportada e discutida várias vezes pelos seus protagonistas: a forma do vazio interior da arquitetura do alto forno, também conhecido como o perfil do alto forno.

Ipanema teve os dois únicos altos fornos em operação no Brasil entre 1818 e 1888. Alto forno é o nome dado a um forno de operação necessariamente contínua, $24 \mathrm{~h}$ por dia, sete dias por semana, meses a fio, em que o minério de ferro, na forma de óxido, é transformado em ferro metálico. Como explicou o romancista Monteiro Lobato: "Minério de ferro é um óxido de ferro sem nenhuma utilidade para o homem enquanto nesse estado. Para que se torne útil havemos de separar o ferro do oxigênio. (...) Como sob a ação do álcool o homem mais sisudo faz coisas que 
jamais faria em estado sóbrio, assim sob a ação inebriante do calor o pobre oxigênio perde a cabeça e troca a sua ligação de milhões de anos com o ferro por um "rabicho" de momento. (...) Esse gás-sereia com que o homem rompe o velhíssimo matrimônio é o monóxido de carbono" [4, 5].

A Fábrica de Ferro de Ipanema esteve predominantemente sob direção de engenheiros militares. Apesar de a Fábrica ter demonstrado a viabilidade técnica da operação de uma siderúrgica nos trópicos, e apesar da demanda mundial de ferro ter crescido enormemente com as máquinas a vapor, as ferrovias, os navios e o uso de ferro na construção civil e arquitetura, e apesar da fundição de ferro ter sido um florescente negócio no século XIX brasileiro, nenhum empresário brasileiro arvorouse a investir na produção da matéria prima dessa indústria, o ferro gusa. O Barão de Mauá ganhou muito dinheiro no ramo da fundição [6], assim como ingleses no Recife [7] e no Rio de Janeiro e imigrantes alemães em S. Paulo [8], mas sempre utilizando como matéria prima lingotes de ferro gusa ${ }^{1}$ importados predominantemente do Reino Unido. Pelo que se sabe, só a fundição do Arsenal da Marinha do Rio de Janeiro usou ferro gusa produzido em Ipanema [9].

Os altos fornos do século XIX tipicamente tinham mais de oito metros de altura e um grande vazio interior na forma de dois troncos de cone unidos no maior diâmetro, que tinha da ordem de 2 metros. Pode parecer, mas não é uma chaminé. A forma de duplo tronco de cone está associada à sua função: o equipamento trabalha com dois fluxos de matéria em contracorrente: minério e carvão são adicionados por cima e demoram horas para descer do topo até a base, onde fica o cadinho e por onde sai o ferro líquido, enquanto o ar soprado por um tubo chamado algaraviz, colocado a apenas 0,5 metro da base, reage com o carvão e forma gases que sobem até o topo, saindo pela chaminé. O carvão, adicionado no topo, desce reagindo com os gases até finalmente entrar em combustão com o ar injetado pelo algaraviz. Os produtos gasosos da combustão incompleta do carvão reagem quimicamente com o minério de ferro e arrastam para cima o oxigênio da sua composição química, liberando o ferro metálico líquido para descer até o cadinho. Até hoje os altos fornos são o principal equipamento usado para produzir ferro metálico. Seu vazio interior continua sendo composto por dois cones invertidos e uma base. A figura 1 compara formas e dimensões do corte de um alto forno moderno e do alto forno de Ipanema.

O que mudou nos últimos 200 anos? Para viabilizar o aumento da produção diária, a altura do alto forno aumentou quatro vezes, enquanto o diâmetro da base aumentou 28 vezes. A evolução na mudança no perfil foi determinada pela busca de aumentar a produtividade do forno, ou seja, a quantidade de ferro líquido produzida por dia, de 1 tonelada para 15.000 toneladas. A forma do vazio interior tem sido objeto de discussão em livros publicados desde o século XVIII. Um livro recente sobre altos fornos afirma que "não há prática científica, teoricamente justificada, do cálculo do perfil do alto forno. As dimensões são estimadas com base em fórmulas empíricas e experiência anterior, que leva em conta as condições de operação, por exemplo o tipo de carga que receberá."[10]

\footnotetext{
${ }^{1}$ Ferro gusa é o nome que se dá ao metal produzido nos altos fornos. Contém aproximadamente $94 \%$ de ferro, $4 \%$ de carbono, $2 \%$ de silício e outras impurezas. Dois tipos podem ser produzidos, o "ferro branco" e o "ferro cinzento", adjetivos que se referem à cor do metal na superfície de sua fratura, quando é rompido por impacto.
} 


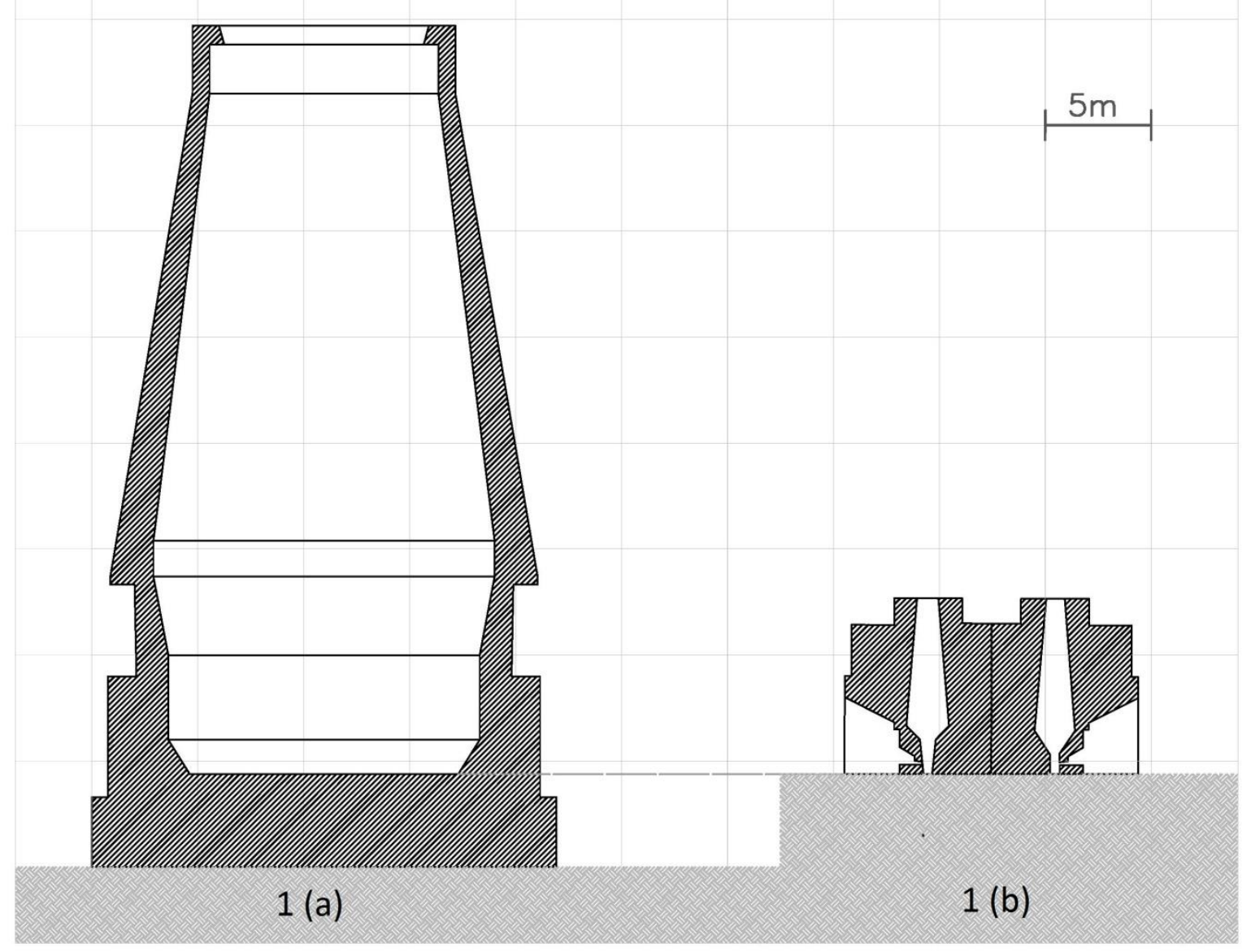

Figura 1. (a) Perfil de um alto forno construído no ano 2000, à esquerda, (b) comparado com os perfis dos altos fornos gêmeos de Ipanema em 1818, na mesma escala.

\section{Os perfis do vazio interior dos altos fornos de Ipanema}

Na literatura até agora disponível, foram encontradas oito descrições dos perfis dos vazios interiores dos altos fornos de Ipanema ao longo de sua história, e este trabalho traz mais três, resultado de escaneamentos feitos em outubro de 2015 por equipe da Universidade de Ferrara (Itália) e em novembro de 2016 por equipe da Escola Politécnica. O mais antigo perfil do vazio interior dos altos fornos de Ipanema foi desenhado a pedido do segundo diretor da Fábrica. Frederico Luis Varnhagen (nascido em 1783-falecido em 1842), que os construiu em 1817. Varnhagen utilizou, em Ipanema, muitas das características dos altos fornos que ele operou em Figueiró dos Vinhos, Portugal [11]. A planta e o corte vertical da Fábrica de Ferro de Ipanema desenhados em 1817 são ricos em detalhes do alto forno, das forjas de refino, dos foles de insuflação de ar, das rodas d'água de acionamento, dos edifícios, da rampa de carregamento, mas não explicitam a parte inferior do vazio interior, que deveria incluir as 3 partes cruciais, a rampa, o "laboratório" e o cadinho. A literatura apresenta duas versões muito parecidas desse desenho, uma que consta do original alemão do livro chamado Pluto Brasiliensis [12] -- mas não da tradução brasileira -- e outra num livro editado em Portugal [13]. Guilherme 
Eschwege (1777-1855) assina os desenhos em seu livro, enquanto o livro editado em Portugal, pelo genro de Varnhagen, não tem assinatura. Como o tenente engenheiro Rufino José Felizardo foi oficialmente encarregado de desenhar a planta da Fábrica, é provável que seja ele o autor. A figura 2 apresenta uma parte do desenho, na versão portuguesa, destacando o corte vertical dos altos fornos gêmeos, os foles, a roda d'água e o perfil do vazio interior, mas sem detalhamento da parte inferior, que deveria mostrar a rampa, laboratório e cadinho. O desenho retrata a estrutura permanente dos altos fornos, já que rampa, cadinho e laboratório seriam refeitos a cada campanha.

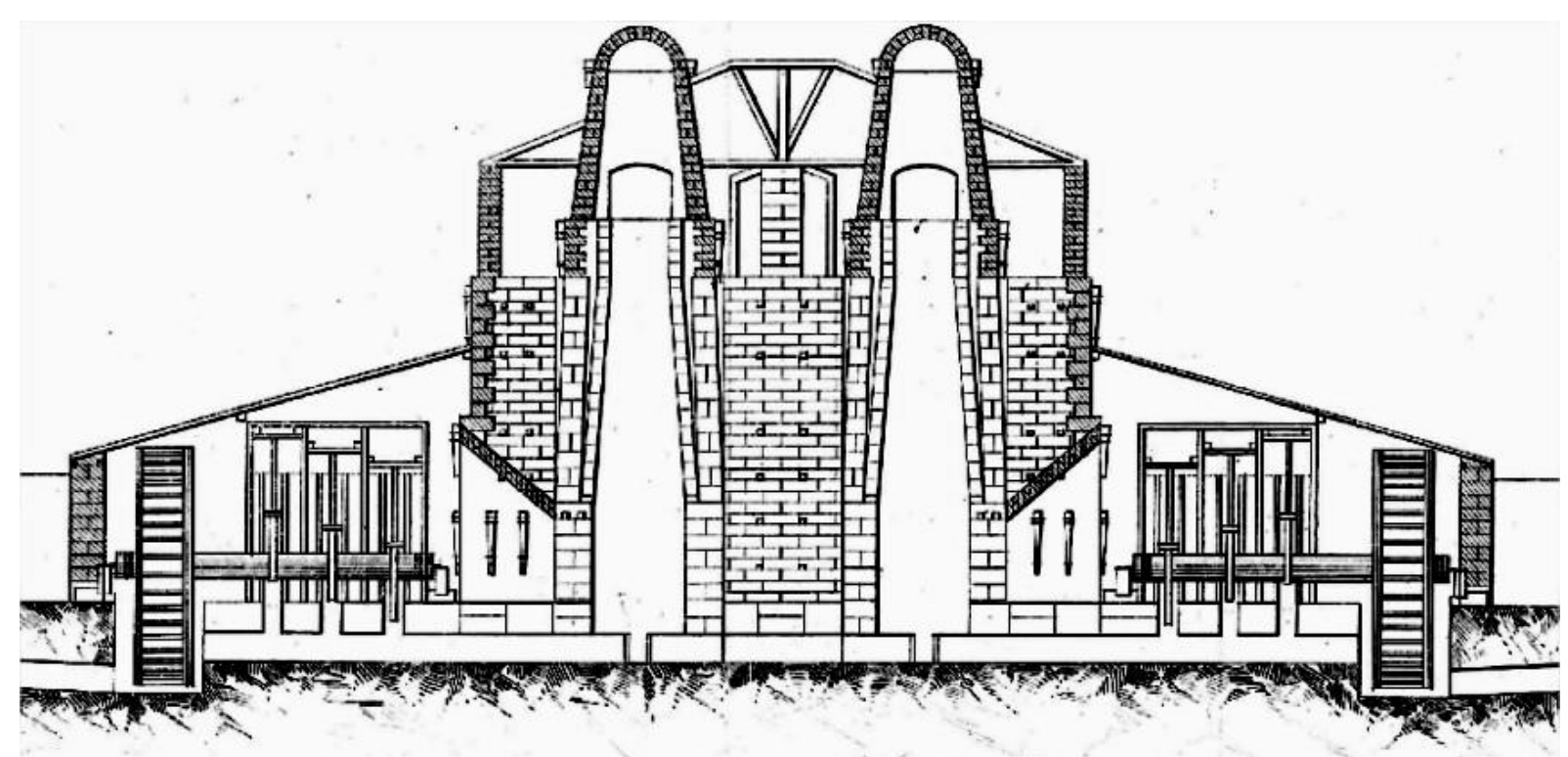

Figura 2. Parte de desenho publicado no livro, em 1857, descrevendo os altos fornos da Fábrica de Ferro de Ipanema [13].

Minério e carvão eram alimentados pela parte de cima do forno, chamada de goela, através de uma janela de viga curva que se nota na figura 2. $\mathrm{O}$ ar era soprado por um tubo, chamado de ventaneira ou algaraviz, não detalhado nesse desenho, alimentado por três foles de madeira acionados por uma roda d'água. $O$ exato mecanismo de acionamento dos foles não está completamente esclarecido mas, conforme se vê na figura 2, parecem existir 3 cames deslocados de $120^{\circ}$, montados no eixo da roda d'água. Os cames acionavam hastes que empurravam defasadamente plataformas horizontais dentro de caixas retangulares, o movimento das plataformas comprimia o ar que era conduzido até o algaraviz. Os tubos que conduziam o ar não são mostrados na figura. A disposição dos cames está mais claramente apresentada na versão portuguesa do desenho do que na versão alemã de Eschwege. O metal líquido era vazado uma vez a cada oito horas, pela frente do forno, na direção do leitor. O gás quente saía por janelas laterais nas chaminés cônicas, para evitar que água de chuva caísse na goela do forno.

A primeira descrição completa do perfil do vazio interior dos altos fornos de Ipanema foi feita numa carta do diretor Varnhagen para seu colega Eschwege que estava em Minas Gerais. A carta, datada de 27 de abril de 1817, permitiu desenhar o perfil do lado esquerdo da figura 3. A primeira fusão da primeira campanha desse alto forno realizou-se em 1 de novembro de 1818, produzindo cruzes de ferro que até hoje 
ornam uma praça na FFI e o museu de história de Sorocaba. A seção horizontal do forno não era circular, mas elíptica, com eixo maior alinhado na direção fundo-boca de vazamento de metal, tanto na junção entre rampa e cuba quanto na altura do algaraviz. O forno do lado esquerdo tinha uma única entrada de ar, a $40 \mathrm{~cm}$ do solo, e essa entrada separava a parte inferior chamada de cadinho, onde se acumulavam o metal e a escória em estado líquido, da parte superior chamada de laboratório (ou obragem).

Cronologicamente, o terceiro perfil conhecido foi publicado por Leandro Dupré (1853-1896) nos Anais da Escola de Minas de Ouro Preto [14], com legenda datando o perfil como de "1818" mas que deve ser posterior, como se discutirá a seguir, com base em comentário de José Bonifácio de Andrada e Silva (1763-1838), o famoso "Patriarca da Independência". Esse perfil foi reproduzido na figura 3(b). Chama a atenção a redução da altura do laboratório e o aumento da altura da rampa, resultando num aumento do ângulo da rampa. José Bonifácio se considerava um metalurgista [15]. Estudou em 1792-1793 na Escola de Minas de Freiberg (Saxônia) com A. G. Werner (1749-1817), e tinha em sua biblioteca uma conferência daquele geólogo sobre siderurgia. Foi contratado como professor de metalurgia na Universidade de Coimbra e dirigiu Varnhagen e Eschwege na Ferraria de Figueiró dos Vinhos (1802-1804).

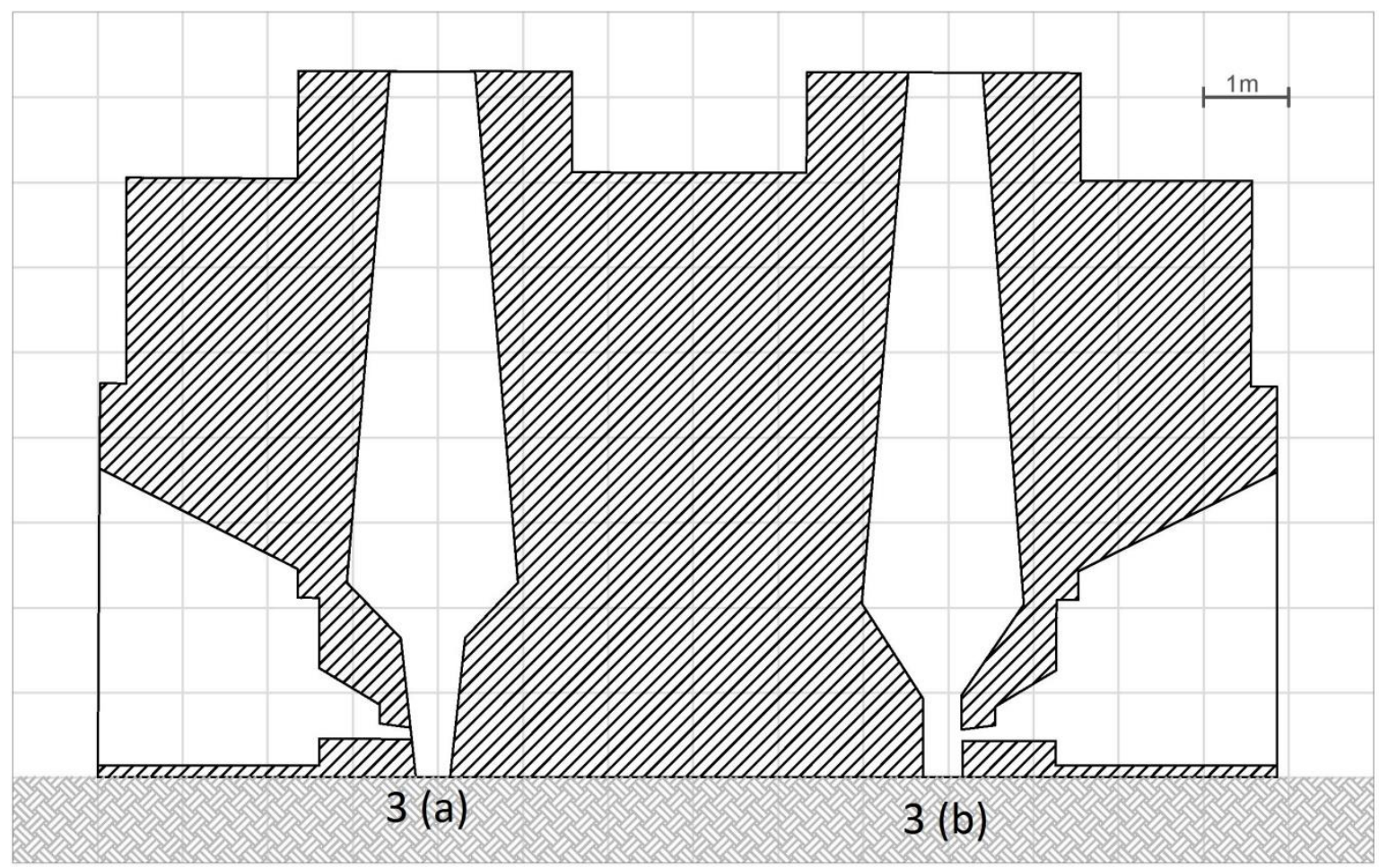

Figura 3: Perfis dos altos fornos de Ipanema: (a) o AF desenhado a partir dos dados de Varnhagen no livro de Eschwege [12], e à direita (b) o AF desenhado por Dupré [Erro! Indicador não definido.] e identificado como "1818", mas que certamente é posterior.

Quando José Bonifácio voltou ao Brasil, logo visitou a Fábrica de Ferro de Ipanema, em abril de 1820, que já tinha tido duas campanhas de produção contínua de ferro 
nos altos fornos, por dois meses e meio em 1818 e por oito meses em 1819 [12]. Bonifácio escreveu uma Memória sobre essa visita, enviada ao governador de S. Paulo [16]. Dentre as críticas que Bonifácio fez ao trabalho de Varnhagen, uma delas tem interesse direto para a discussão do perfil do alto forno: Bonifácio afirma que o ângulo da rampa do alto forno (em relação à horizontal) não era íngreme o suficiente para uma boa marcha do forno, sendo de apenas $45^{\circ}$. Bonifácio construiu um raciocínio para explicar interrupções da boa marcha, que seriam causadas pelo acúmulo da carga nessa rampa pouco íngreme, assunto mais detalhadamente discutido em outro artigo [17]. É possível que quem descreveu as interrupções tenha sido o técnico sueco Lourenço (Lars) Hultgren, que veio com a primeira equipe de operadores do forno, ajudou Varnhagen a construir e operar os altos fornos mas foi demitido por ele em janeiro de 1820. Bonifácio elogiou Hultgren, na sua Memória [16]. O exame do perfil da figura 3(a), desenhado segundo informações de Varnhagen, confirma a situação descrita por Bonifácio, o ângulo de $45^{\circ}$ na rampa, $\mathrm{O}$ perfil da direita mostra uma rampa mais íngreme, de $60^{\circ}$, a direção sugerida Bonifácio. Com base no comentário de Bonifácio, feito em 1820, é difícil admitir-se que o perfil da direita seja de fato de 1818, diferentemente do que indica Dupré em seu artigo [Erro! Indicador não definido.].

Dupré começou a trabalhar em Ipanema em 1878, e não se sabe a origem desse desenho ao qual ele atribui a data de 1818. Como Varnhagen deixou a Fábrica em 1821, ainda aguardando a chegada de operários alemães que ele solicitara, parece pouco provável que ele tenha tido interesse e tempo para mudar o perfil depois da crítica de 1820. A mudança pode ter sido feita por algum dos diretores posteriores a Varnhagen, como o Rufino Felizardo (1821-1825), que utilizou o apoio do sueco Lars Hultgren, recontratado em 1822. Esse sueco havia operado o alto forno de Carl Hedberg em Hagelsrum, Suécia [17,18].

Um diretor que reportou a intenção de fazer mudanças nos altos fornos foi João Bloem (1798-1851), diretor da fábrica num novo momento de prosperidade, entre 1835 e 1842. Bloem encomendou (em 1835) um conjunto de livros sobre siderurgia, incluindo os clássicos de Karsten [19] e de Hassenfratz [20]. Esses dois autores são os dois clássicos mundiais da siderurgia na primeira metade do século XIX. Neles, a questão do ângulo da rampa foi muito discutida.

Jean Henri Hassenfratz (1755-1827) foi assistente de Lavoisier, inspetor de minas, membro do clube dos jacobinos, um dos fundadores da École Polytechnique de Paris e professor na École des Mines de Paris. Publicou sua obra maior, La Sidérotechnie, ou l'art de traiter les minerais de fer [20], em 1812, em quatro volumes, depois traduzido para várias línguas. O livro trata quase que unicamente dos altos fornos a carvão vegetal, pois até aquele momento a França pouco usava o carvão mineral na siderurgia. É dele que foi tirada a expressão "vazio interior" (vide intérieur) usada no presente artigo. Dentre os muitos assuntos tratados no livro, ele comentou sobre a grande variação de ângulos de rampa utilizados na Europa, incluindo figuras representativas, que foram reapresentadas em artigo recente [17].

Karl Johann Bernhard Karsten (1782-1853) tornou-se responsável, aos 25 anos, por toda atividade metalúrgica da Alta Silésia, na Alemanha, incluindo uma fábrica de armas para o exército da Prússia. Deu aulas de siderurgia em cursos abertos da Universidade de Breslau e foi funcionário governamental responsável pela 
mineração e metalurgia na Prússia. Foi editor da revista Archiv fur Bergbau und Hüttenwesen (Arquivo de Mineração e Metalurgia), de 1818 a 1831 e autor do clássico Handbuch der Eisenhüttenkunde (Manual de Siderurgia) publicado em Berlin em 1816, em 2 volumes. O livro aborda as propriedades físicas e químicas do ferro, os minerais, os combustíveis e a construção dos foles, a produção de gusa e fabricação objetos moldados e por fim a preparação do ferro batido e do aço. Este livro também trata principalmente dos altos fornos a carvão vegetal.

O Manual de Siderurgia de Karsten ficou tão afamado que foi citado por pelo menos dois dos diretores de Ipanema: Capanema diz que Antonio Manuel de Mello (diretor entre 1844 e 1846) "agarrado com seu Karsten e metido no meio dos fornos, a cabo de dois anos conseguiu pagar todas as dívidas (da Fábrica), pagou todas as despesas e começou a apresentar um saldo de 8 contos. Ele tinha por mestre fundidor um velho escravo e por afinador um matuto paulista, dispensava, pois, esse aparato de mestrança"[21]. Outro diretor, Ricardo José Gomes Jardim (diretor em 1849 e 1850), ao defender que se evitasse a excessiva moagem do minério, escreveu que "segundo Karsten, o mineral deve ser tanto mais pequeno quanto mais baixos forem os fornos; contudo é preciso não convertê-los a poeira por que isso seria um meio de fechar as passagens ao ar e de engorgitar a cuba" [22 ]

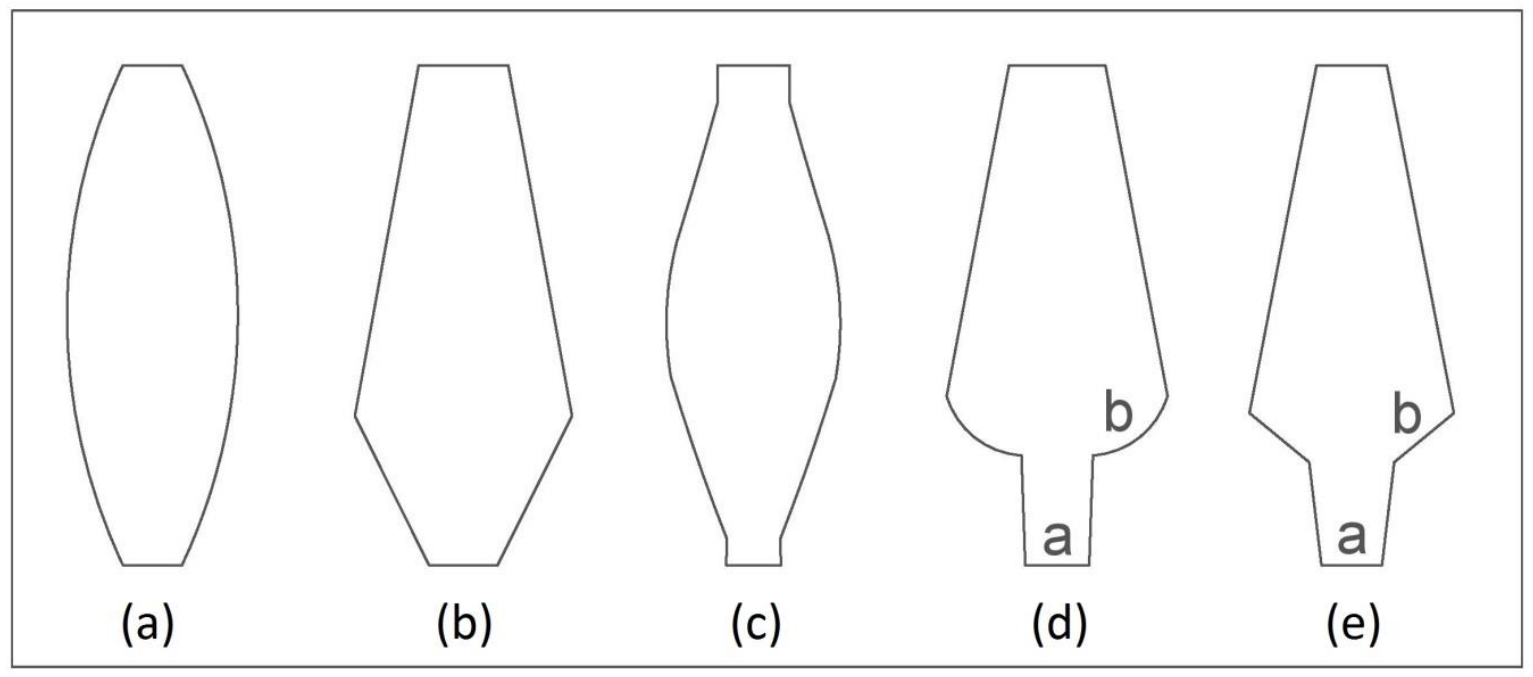

Figura 4. Evolução dos perfis dos altos fornos, segundo Karsten [19]

O que dizia Karsten sobre a escolha de perfis para um alto forno? Ele, assim como Hassenfratz, afirmava que os perfis do vazio interior usados em diferentes lugares da Europa podiam ser muito diferentes, e que isso estava associado ao tipo de minério usado. A figura 4 mostra quatro perfis muito diferentes do vazio interior de altos fornos, retirados da prancha IV da versão francesa do seu Manual de Metalurgia do Ferro, de 1830. Livros daquela época tinham parágrafos numerados. Uma tradução livre do parágrafo de número 726 diz que "O local em que a cuba é mais larga é chamado de ventre. Colocado tanto no meio da altura do forno, como no primeiro terço a partir do solo, ele é largo para os minérios fusíveis, tratados com carvão denso e vento forte (fig. 4 (b)), enquanto que para os minerais refratários a largura é diminuída, usa-se carvões pouco densos e vento fraco (figura 4 (c)); mas, dado que o estreitamento produz muita pressão nas camadas inferiores, vê-se nas 
figuras 4 (d) e 4 (e) que a obragem (região a) é encimada por uma superfície cônica ou um toróide (região b)" . No parágrafo 784 ele repete o argumento, quando diz que "quando alimentados com minérios fusíveis e carvão (vegetal) denso, os fornos devem ser largos e as rampas devem ser mais longas; quando os fornos mais estreitos são carregados com minérios refratários, o combustível deve ser ligeiro e a rampa mais curta. ... Se, pela natureza do combustível, for necessário um vento muito forte, a rampa deve ter ao menos um ângulo de 60 com o horizonte".

Os comentários de Karsten permitem outro olhar sobre a escolha de Varnhagen pelo ângulo de 45․ Como ele sabia que o minério de Ipanema continha alto teor do óxido de ferro magnetítico, e que esse tipo era considerado um minério refratário, sua opção por um perfil com rampa curta, ou seja, de baixo ângulo, era compatível com o uso descrito por Karsten. Mesmo assim, pelo que indica o desenho de Dupré na Figura 3 (b), pouco depois de Varnhagen o perfil usado já tinha um ângulo de rampa maior, talvez construído pelo diretor da Fábrica entre 1835 e 1842, o major João Bloem (1798-1851).

A direção de Bloem coincide com um momento de investimento em Ipanema. $O$ governo do Regente Feijó (1835-1837), com o apoio do presidente da província de S. Paulo, Tobias de Aguiar, que tinha interesses em Sorocaba, decidiu financiar a ida de Bloem para Alemanha e Inglaterra para comprar equipamentos, instrumentos de laboratório químico e contratar mão-de-obra para a Fábrica. Trouxe 44 alemães, dentre eles Friedrich Holtz (1809- 1880?), que lá ficaria por 50 anos. João Bloem foi muito ativo na produção de objetos de ferro fundido demandados pelos donos de engenhos de açúcar do quadrilátero do açúcar (Sorocaba, Piracicaba, Mogi Guaçu e Jundiaí, conforme [23],

Em 1842, Feijó e Tobias de Aguiar lideraram uma revolta contra o governo conservador, com base em Sorocaba. A chamada Revolta Liberal durou pouco, os líderes foram presos e, apesar de não ter tido participação direta, Bloem foi destituído da direção da Fábrica. Os diretores seguintes conheciam menos de siderurgia e, apesar de vários deles citarem a leitura do livro de Karsten, a produção de Ipanema caiu. A altura do alto forno foi preocupação de muitos dos que passaram por Ipanema. Varnhagen o construiu com 8,3 metros, e nenhum dos outros diretores arriscou-se a aumentar-lhe a altura, apesar de muita discussão. Já em 1849 o diretor Ricardo José Gomes Jardim, em relatório ao Ministério da Guerra (7/02/1849), considerava que, sendo o mineral reconhecidamente de difícil fusão, os fornos eram muito baixos. Ele sugeriu que pelo menos um dos fornos fosse alteado para 11 metros. Maior elevação exigiria maior ventilação, o que seria incompatível com o emprego de um só algaraviz, mas tal reforma não poderia prejudicar o segundo alto forno. Por fim, nada alterou.

Depois de 10 anos de decadência, a Fábrica chegou a ser desativada em 1860, por decisão do Ministério da Guerra. Em 20 de abril de 1860 o secretário do Arsenal de Guerra publicou um edital de compra de serviço de transporte, de Santos para Montevideo, de 34 toneladas de máquinas e material retirado da fábrica de ferro de São João de Ypanema para serem transportados para uma futura fábrica de ferro que seria construída no Mato Grosso, o que nunca aconteceu.

O jornal O Correio Paulistano, edição de 21/06/1862, ao relatar a passagem do presidente da província por Ipanema e constatar o estado ruinoso das instalações, 
comenta que o presidente examinou cerca de 50 livros científicos da sua biblioteca e recomendou ao encarregado da Fábrica, tenente Francisco Antonio Dias, que tivesse grande cuidado com eles. Apesar disso, os livros desapareceram pouco depois.

Depois de fazer uma reavaliação do potencial da Fábrica em 1863, o engenheiro militar Guilherme Schüch Capanema (1824-1908), brasileiro que estudou na Escola de Minas de Freiberg (1848-1849), defendeu pela imprensa a reabertura de Ipanema: O aço de Ipanema foi ensaiado na Prússia e teve os maiores elogios. Essa Fábrica, que consumiu centenas de contos aos cofres públicos, está por terra e completamente desmantelada; isso deve realmente assustar a quem aprecia os resultados sem indagar as causas. Todo o mal de Ipanema foi a falta de direção, $e$ talvez algum ódio à indústria pelo costume em que estamos de ouvir clamar por toda parte que o Brasil só deve ser o país da lavoura; e ninguém acrescenta: - para ser pisado aos pés estranhos à sua própria custa [24 ].

Depois de 14 anos de ministérios conservadores, os ministérios liberais entre 1864 e 1866 decidiram pelo reinvestimento em Ipanema. Nilton Santos descreve a participação de Capanema no processo, inclusive a indicação do novo diretor [25].

Joaquim de Souza Mursa (1827-1893), engenheiro formado pela Escola Militar em 1857, enviado pelo Exército para estudos na Europa, fez cursos de construção de máquinas, química prática, química analítica, siderotecnia, docimasia (teor de metal nos minérios) e análise pirognóstica na Escola de Minas de Freiberg, Alemanha, entre 1860 e 1861. Assumiu a direção da fábrica em julho de 1865 e lá ficou até 1890. Em 1882 Mursa contratou um engenheiro de minas recém formado pela primeira turma da Escola de Minas de Ouro Preto, engenheiro Leandro Dupré Junior, que escreveu em 1884 um artigo detalhado sobre a situação da Fábrica, trazendo vários desenhos de perfis [14].

A figura 5 apresenta dois perfis projetados por Mursa, em diferentes momentos, conforme descritos por Dupré [14]. Como se nota comparando a figura 3 com a figura 5, a primeira intervenção foi abrir uma galeria no meio da largura do forno, de modo a permitir a entrada de dois sopradores de ar em cada alto forno, objetivando o aumento da produção para três toneladas por dia [26]. Até certo ponto, mais vazão de ar permite queimar mais rapidamente o carvão e, com isso, o aumento da redução do minério de ferro e a formação do ferro metálico. Ele não mudou a altura da injeção do ar, que continuou a $50 \mathrm{~cm}$ do solo, e com isso manteve a altura do cadinho.

Usando suas palavras O laboratório (ouvrage) dos antigos fornos tinha uma altura igual a do cadinho (como se vê na figura $3 \mathrm{~b}$ ). Presentemente tem uma altura tripla (figura 5a), como urge a qualidade do minério aqui empregado. Com as novas dimensões, com o minério bem ustulado, com o emprego de ar quente e de lenha seca em fornos, a produção do forno será de 3 toneladas diárias [26].

No perfil de 1865, ao aumentar a altura do laboratório, ele aumentou também o ângulo da rampa para $70^{\circ}$ e acrescentou um ventre (parte cilíndrica do perfil) de um metro de altura, tendo com isso diminuído a cuba de $6 \mathrm{~m}$ para $4,5 \mathrm{~m}$, pois ele não alteou o alto forno. 
Mursa voltou à Europa em 1873, com objetivo de contratar mão de obra especializada e comprar novos equipamentos. Só na Áustria ele encontrou operários experientes na operação de altos fornos com carvão vegetal.

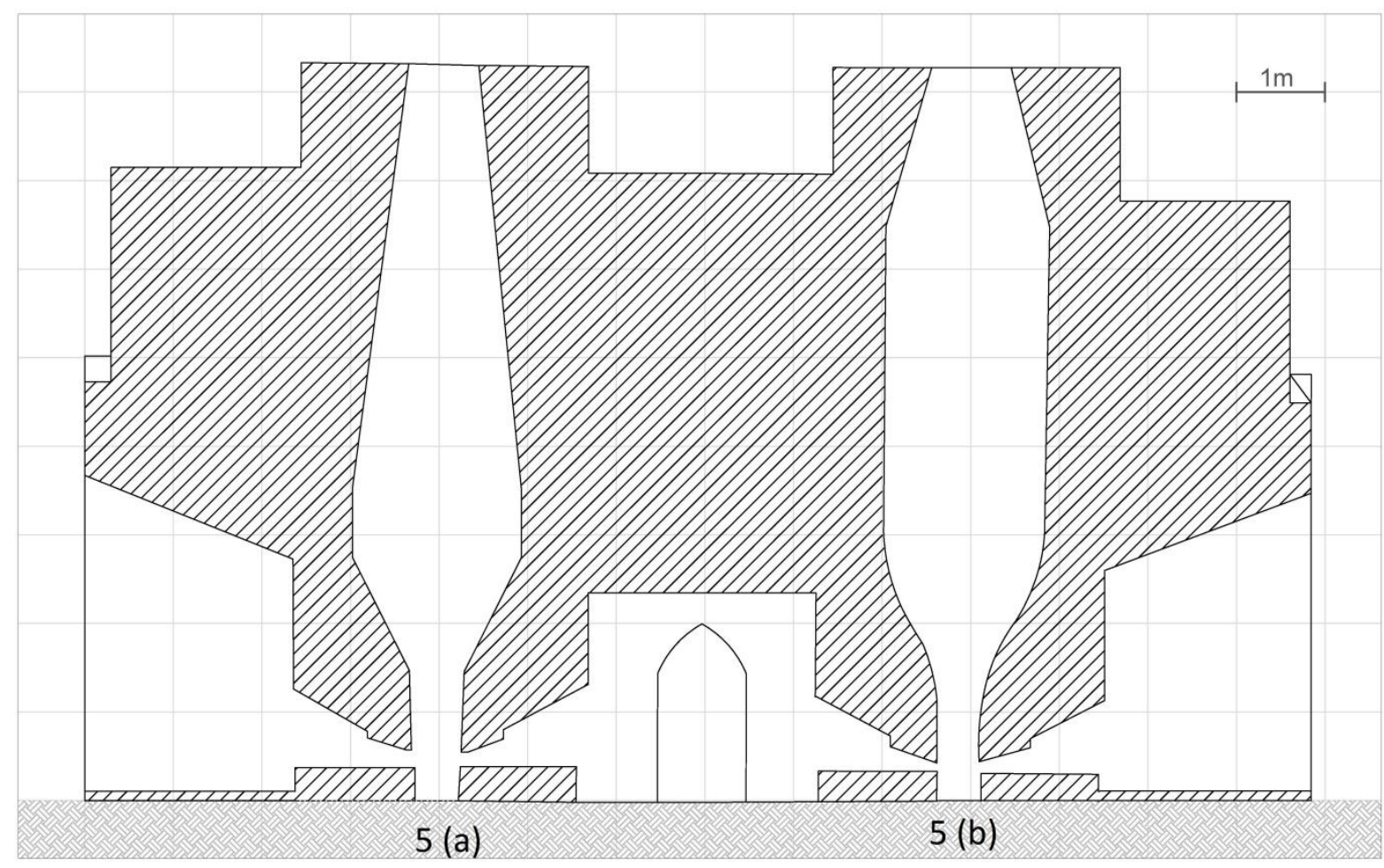

Figura 5. 0 alto forno 5(a) está desenhado com o perfil atribuído a reforma de 1865, que introduziu uma galeria entre os dois fornos para instalar o segundo algaraviz, e o alto forno 5(b), a direita, está desenhado com perfil atribuído à uma reforma de 1885, segundo Dupré [14].

O perfil da figura $5 \mathrm{~b}$, que o artigo de Dupré data de 1885, mostra a manutenção da altura total de $8,3 \mathrm{~m}$ e da largura de $1,8 \mathrm{~m}$, o aumento do ventre para $3,5 \mathrm{~m}$ de comprimento na altura e a manutenção das dimensões básicas da rampa, laboratório e cadinho, com a novidade do arredondamento das concordâncias entre o ventre e a rampa e entre a rampa e o laboratório. O volume interno do forno era de $12 \mathrm{~m} 3$. Um perfil com ventre tão longo não é comumente citado na literatura. Dupré afirma que a produção nesse forno, em 1885, era de $2,5 \mathrm{t}$ gusa /dia, com um consumo diário de carvão de 5 toneladas.

A evolução dos perfis permitiu um melhor controle da operação dos altos fornos, em termos dos produtos almejados. Um conhecimento bem disseminado pelos operadores, e citado pelos livros da época, era necessidade de produzir dois tipos de produto, um chamado de gusa cinzento, adequado para fabricar peças por fundição, e outro chamado de gusa branco, adequado para a posterior fabricação de ferro batido, pelo refino. Os nomes referem-se à cor da fratura dos lingotes de gusa quando rompidos por impacto. Os operadores sabiam que uma operação do alto forno com temperaturas mais altas e com mais silício na carga produzia ferro 
cinzento [27]. Uma coleção de objetos de ferro produzidos em Ipanema que o diretor Mursa presenteou o Imperador Pedro II em sua visita à Fábrica, em 1886, incluía lingotes de ferro branco e de ferro cinzento. A análise microestrutural de fragmentos das amostras dessa coleção, hoje sob guarda do Museu Nacional, no Rio de Janeiro, revela a microestrutura típica desses materiais (figura 6). A análise química dessas amostras revelou teores de carbono de 3,4\% no ferro branco, e 4,3\% no ferro cinzento, além de menos de $0,1 \%$ de silício no ferro branco versus $1,4 \%$ no ferro cinzento. Essas composições químicas revelam que os operadores dos altos fornos de Ipanema sabiam controlá-lo de modo a obter o produto que desejavam. Infelizmente o artigo de Dupré, tão detalhista em outros aspectos, pouco se refere a este assunto.

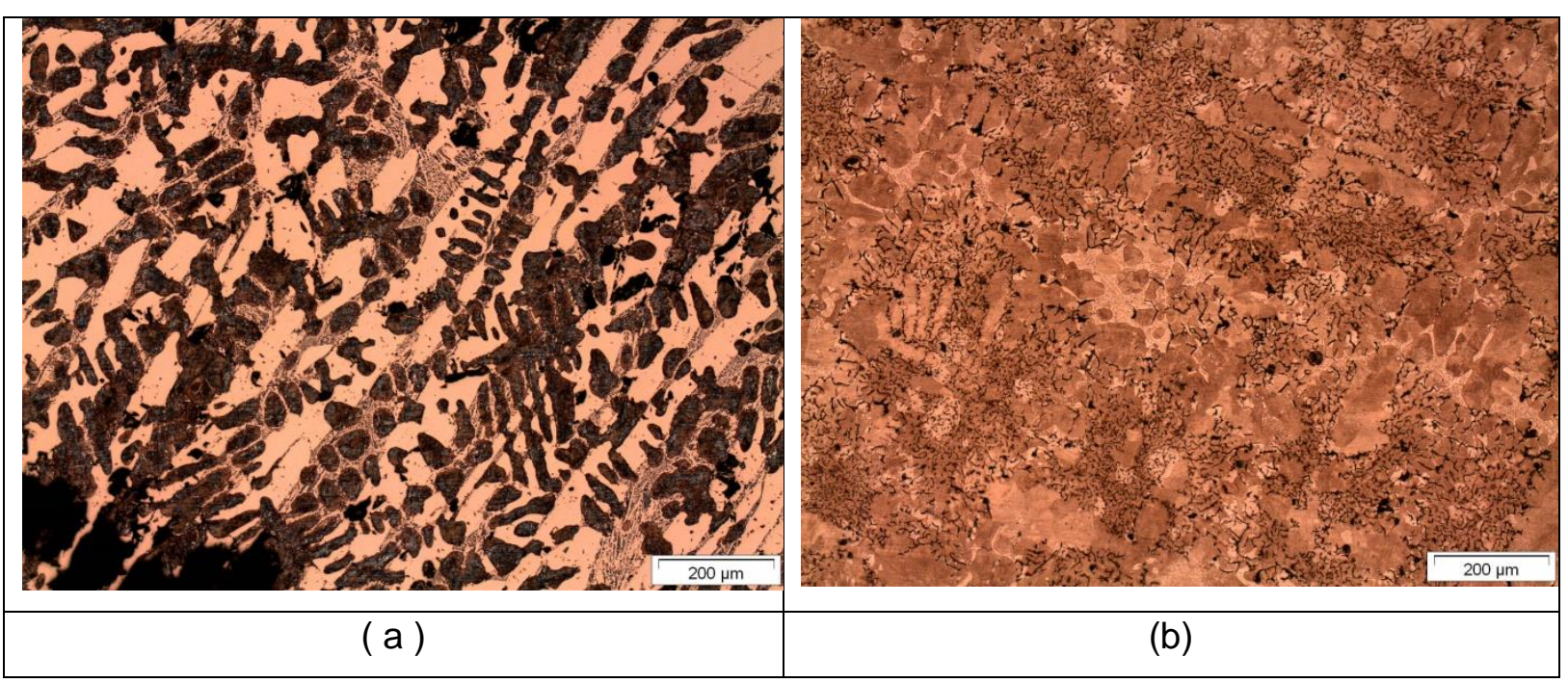

Figura 6. (a) microestrutura de amostra de ferro branco fabricado em Ipanema, mostrando dendritas de perlita e grandes cristais de cementita. (b) microestrutura de ferro branco produzido em Ipanema, com dendritas de perlita entremeadas por veios de grafita, de cor preta.

A produtividade dos fornos, entretanto, ainda era baixa. Mesmo em 1886, a produção anual foi da ordem de 300 toneladas de ferro gusa. O diretor e seu assistente acreditavam que só um forno mais alto poderia aumentar a produção. Durante sua segunda viagem à Europa, em 1873, Mursa contatou seu ex-professor de siderurgia em Freiberg, Theodore Scheerer, que enviou um relatório em que sugeriu altear o alto forno para 10 metros. "melhor será ainda construí-lo com 38 pés (12 metros) se o carvão de madeira empregado for suficientemente duro para resistir ao o peso da carga sem reduzir-se a pó." Fez detalhadas sugestões sobre um novo perfil de alto forno de 10 metros, sobre a vazão necessária de ar e sobre as diferentes proporções de minério carvão e fundentes que a carga deveria ter para obter ferro branco ou cinzento. O desenho do perfil proposto [28] é reproduzido aqui na figura 7(a). Existem diferenças entre as proporções do desenho e as medidas a ele associadas no relatório de Mursa, que talvez possam ser sanadas num futuro acesso ao relatório original em alemão.

Joaquim Mursa acreditava que o aumento da escala daria mais competitividade ao empreendimento de Ipanema, e decidiu em 1878 iniciar a construção de um novo alto forno, agora de 12 metros de altura e 3 metros no maior diâmetro. Sua capacidade seria de 7 a 10 toneladas de gusa por dia, consumindo de 10 a 15 
toneladas diárias de carvão. O forno estava praticamente pronto desde 1882, mas nunca entrou em operação. A justificativa dada por Dupré em 1885 é que o soprador, que deveria ter capacidade para $80 \mathrm{~m}^{3}$ de ar por minuto, em três ventaneiras, não havia chegado. Não há menção, no artigo de Dupré, da intenção de usar o pré aquecimento do ar, apesar dessa técnica ter surgido em 1837 e disseminada rapidamente. Não se deve desconsiderar os outros obstáculos para a operação desse novo alto forno: a dificuldade de obter carvão suficiente para a produção esperada de ferro nesse forno e a falta de mão de obra.

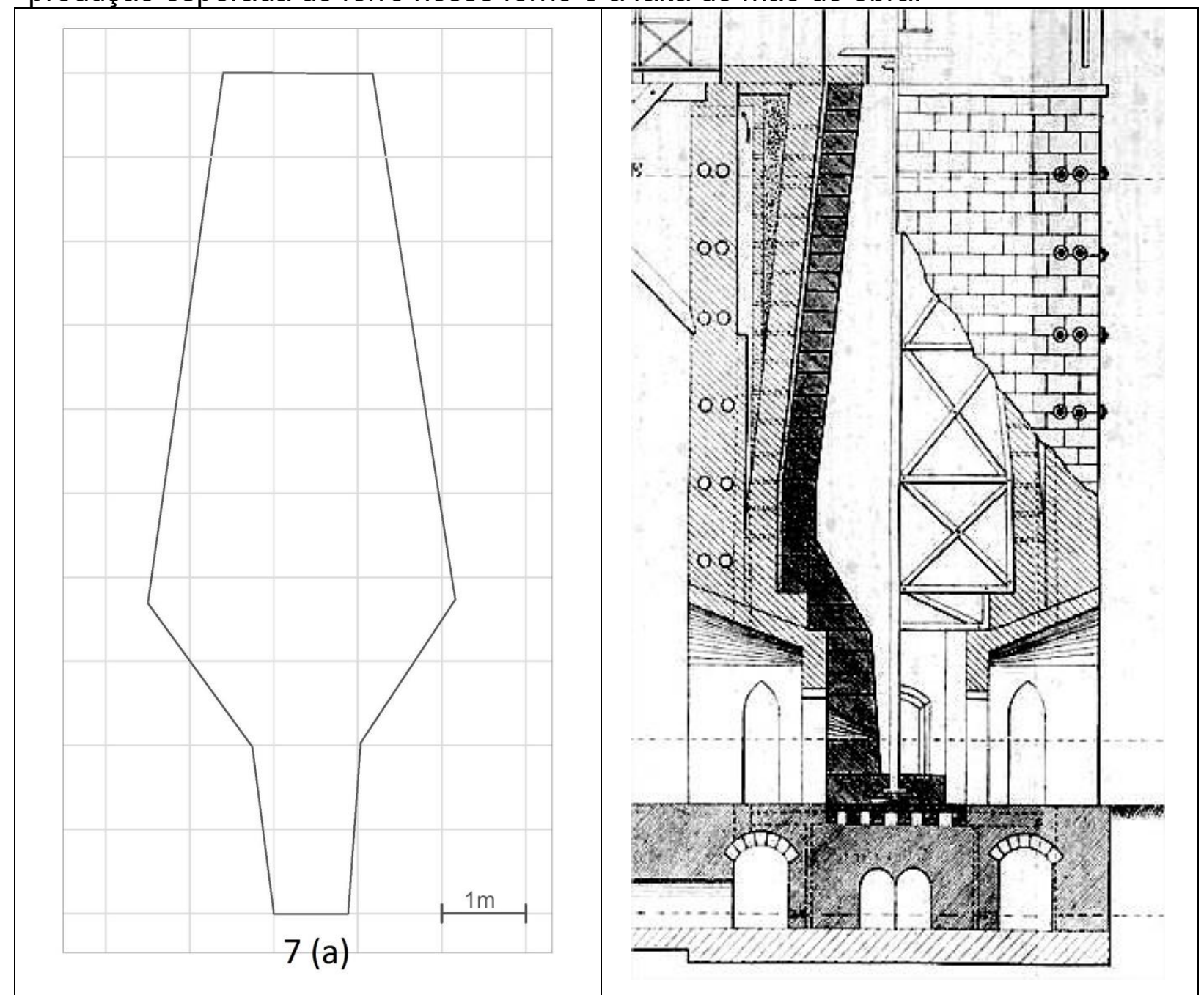

Figura 7. Do lado esquerdo (figura 7 a) vê-se o perfil do vazio interior do alto forno, como proposto por Scheerer [28]. O alto forno do lado direito (figura 7b) é o desenho publicado por Dupré [14]. 


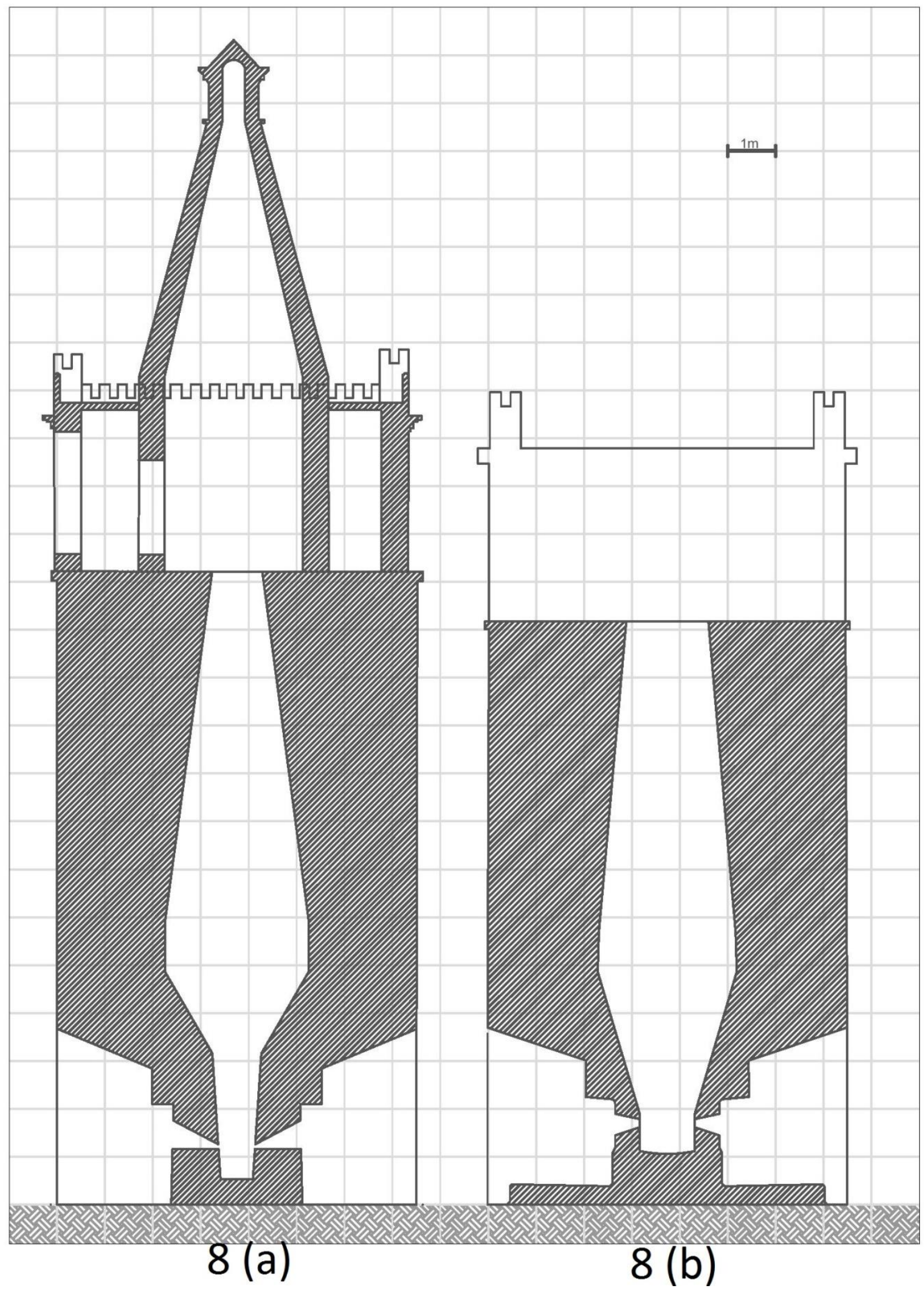

Figura 8. Dois perfis do terceiro alto forno de Ipanema: o da esquerda, 8(a), é o perfil publicado por Dupré () e o da direita, 8(b) é o perfil escaneado pela equipe do CITI USP em 2016.

Com base no escaneamento feito pela equipe do Centro CITI, da Escola Politécnica da USP, representado na Figura $7(b)$, nota-se que o perfil hoje existente não é 
aquele apresentado no desenho publicado no trabalho de Dupré, de 1885, quando ao que consta o forno já estava construído.. Essa situação é surpreendente, pois é dito que aquele alto forno nunca operou, pois nunca chegou o suflador de ar sem o qual o forno não operaria.

A importância da Fábrica para o governo, ou pelo menos para o Imperador Pedro II, pode ser percebida no relato da sua quarta viagem à Fábrica, em 1886, publicado na Revista de Engenharia [29]. $O$ artigo de 3 páginas, que descreve detalhes do percurso de trem até a Estação Ipanema, os dois dias de visita e uma discussão sobre as possíveis origens do minério de Araçoiaba, menciona o novo alto forno em construção e a oficina de fundição "onde teve ocasião de ver correr o ferro; assistiu à fundição de rodas para a estrada de ferro de Baturité; examinou as oficinas de modelação e de máquinas, vendo funcionar os tornos, máquinas de aplainar, etc."

Entretanto, a função econômica da Fábrica de Ferro de Ipanema era questionada. Em 1882, Adolpho Sidow, ex-funcionário de Ipanema e proprietário de uma das várias fundições paulistas da época, solicitou ao Clube Paulistano de Engenharia e Indústria a nomeação de uma comissão "para dar parecer sobre a influência e os resultados da concorrência que oferece aquele estabelecimento custeado pelo Estado aos estabelecimentos congêneres custeados pela indústria particular" [30]

Em 1890 a produção foi interrompida, Mursa deixou a direção para assumir o triunvirato que governou São Paulo após a proclamação da república. Houve tentativa, sem êxito, de privatizar as instalações e, depois de uma série de artigos de Pandiá Calógeras afirmando que o empreendimento era inviável por conta de impropriedades de seu minério [3], a Fábrica foi fechada por decisão do Senado, em 1895.

A escassez de ferro causada pela Primeira Guerra Mundial levou o governo federal de Wenceslau Braz a reabri-la e reinvestir na Fábrica, em 1917, indicando o capitão Antonio Mendes Teixeira à diretoria. Enviado aos Estados Unidos, retornou em 1919 (CORREIO PAULISTANO, 1919) e fez a reforma que alteou o alto forno norte para onze metros, como se vê hoje pela altura da porta de carregamento, na parte de trás do forno. Pouco se sabe, até o momento, da operação dos altos fornos nesse período. É necessário investigar no Arquivo do Exército, no Rio de Janeiro. O CONDEPHAAT fez um levantamento dos remanescentes dos altos fornos em 1974, mas o perfil do alto forno norte foi incorretamente desenhado, imaginando-o semelhante ao alto forno sul, por ser de difícil acesso para medições. O vazio interior atual dos dois fornos gêmeos foi determinado por escaneamento a laser, por pesquisadores da Universidade de Ferrara. A figura 9 reconstrói o corte dos perfis com base nas informações desse escaneamento.

A equipe liderada pelo professor $\mathrm{M}$. Balzani produziu um relevo tridimensional a partir do escaneamento por instrumento Leica P20 (scanner de velocidade: pontos $1 \mathrm{~m} / \mathrm{s}$; precisão na medição única: $3 \mathrm{~mm} / 50 \mathrm{~m}$; erro linear <1 milímetro; desvio padrão:-se a $2 \mathrm{~mm} / 50 \mathrm{~m}$; máxima distância aquisição: 120m). A nuvem global de pontos foi trabalhado no software de código Leica Cyclone 8, com formato original “.imp". O levantamento permite colocar o estudo da Fábrica de Ipanema dentro de uma perspectiva mais ampla. O escaneamento permite criar uma "carteira de identidade" de edifícios da herança cultural, definida em suporte digital, que garantirá 
os processos de restauração, monitoramento, melhoria e proteção. A representação gráfica dos resultados vai além dos limites da ferramenta tecnológica, pois a base de dados morfométrica permite que partes sejam apagadas (para realçar outras) e a densidade de dados seja filtrada de acordo com os objetivos do estudo, como mostra a figura 10. O presente trabalho apresenta cortes dos altos fornos, construídos a partir da base de dados, mas isso é apenas uma fração do que pode ser obtido.

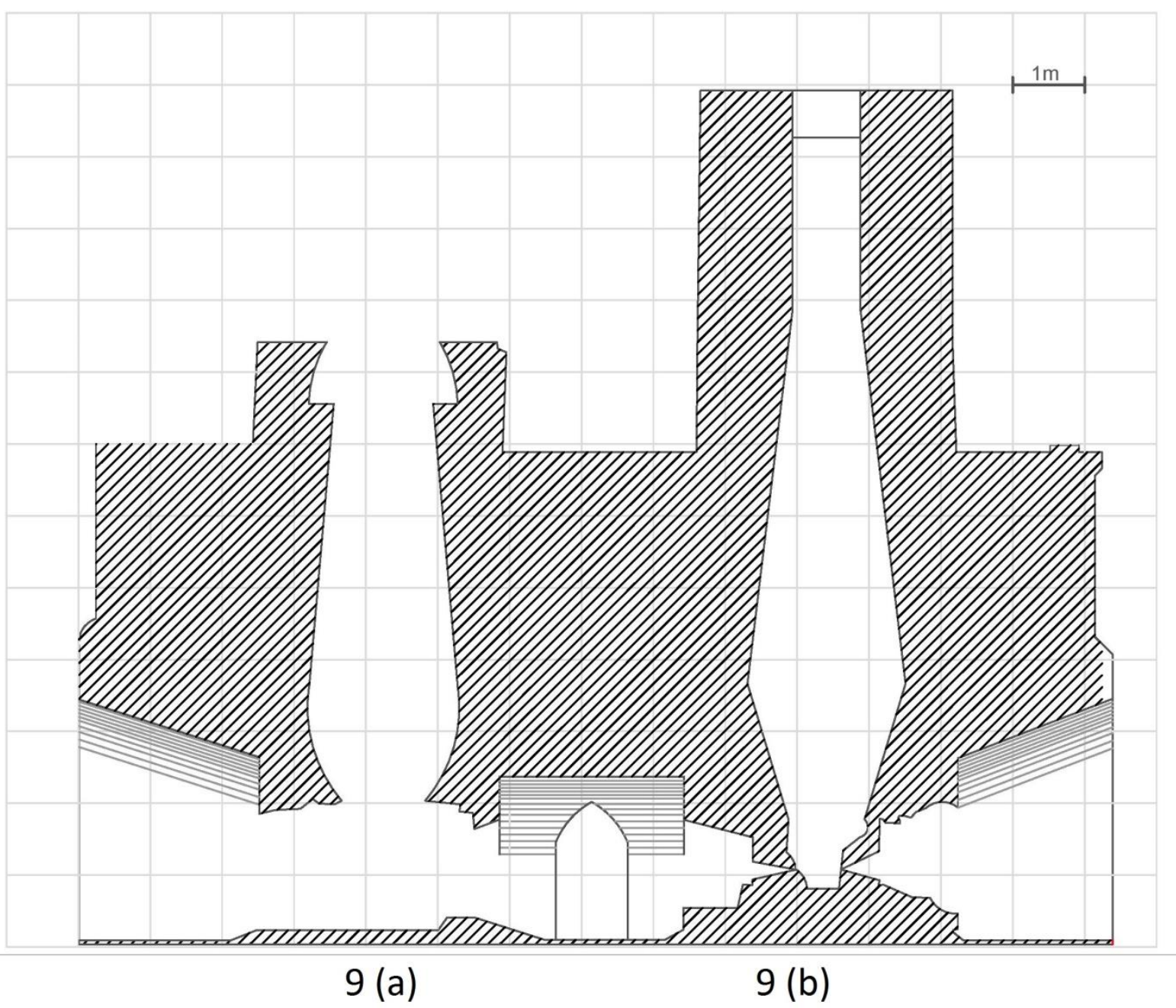

Figura 9. Perfil atual dos altos fornos de Ipanema, como mapeado por escaneamento a laser, pela equipe da Universidade de Ferrara. O Alto Forno Norte, à direita, deve ter sido reformado pelo Capitão Mendes Teixeira, em 1920.

Do perfil do "forno sul" (lado esquerdo da figura) vê-se a cuba, o ventre e a parte alta da rampa. A parte baixa da rampa e a obragem está demolida e com riscos de desabamento. A largura máxima foi ligeiramente aumentada para 2,1 metros. A parte superior da rampa está a 3 metros de altura, na mesma posição dos perfis de 1865 e 1885. A goela é bem maior que a dos perfis do Mursa.

O perfil do vazio interior do "forno norte", figura 9(b), é muito diferente, e repercute no seu formato externo, hoje lá visível. O vazio interior da parte operacional do alto 
forno foi alteado para 11,3 metros, a rampa está mais íngreme, mas não tem ventre e o formato da cuba tem segmento cônico e segmento cilíndrico. O escaneamento pode não ter sido fidedigno no segmento cilíndrico da cuba, por obstáculos ao caminho óptico do laser. Esse desenho é incomum, não foram encontradas referências americanas que justificassem o perfil.

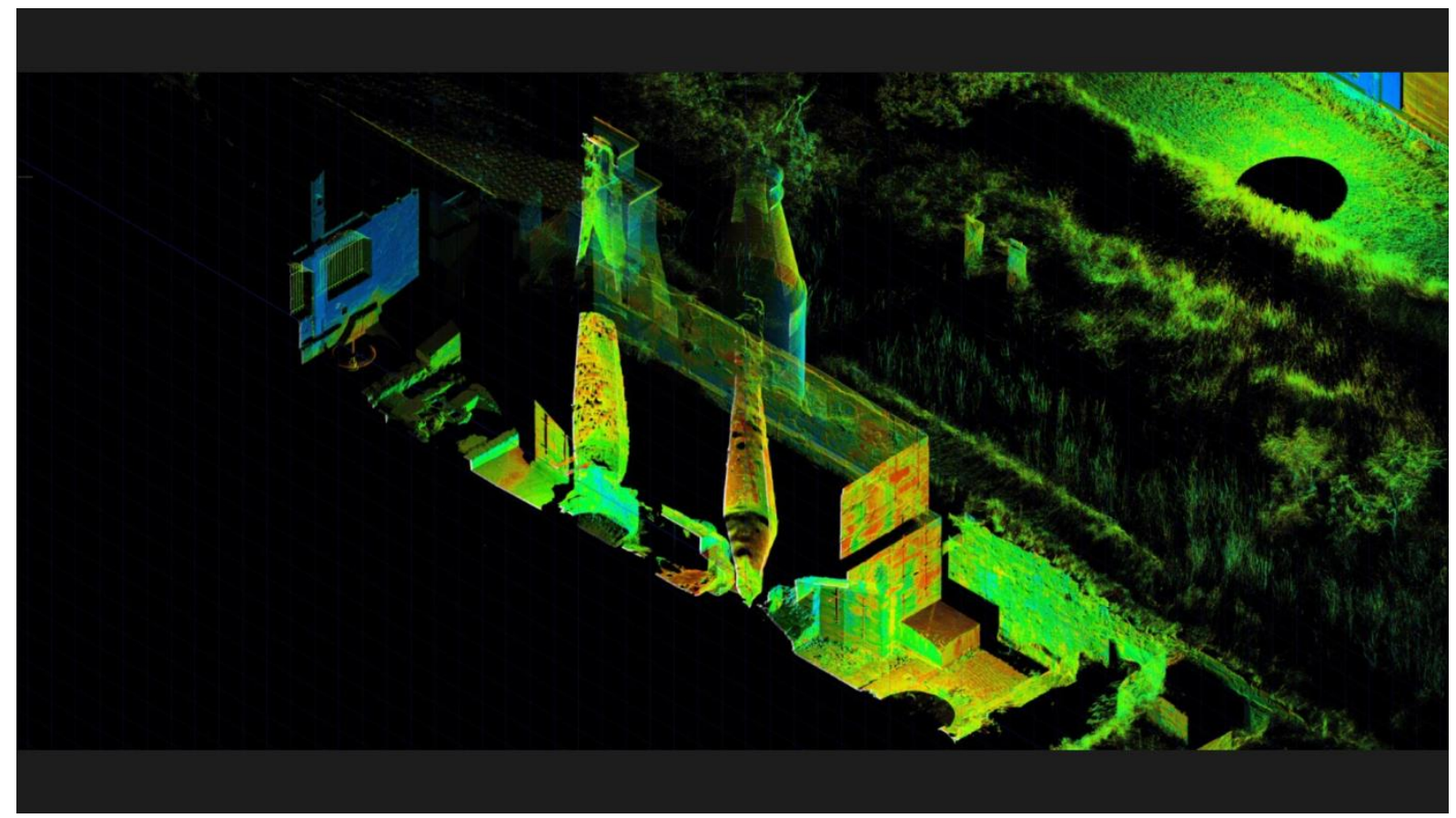

Figura 10, Seção transversal dos fornos gêmeos, feita com base no escaneamento a laser realizado pela equipe da Universidade de Ferrara.

\section{Outros altos fornos do século XIX}

Apesar da crescente demanda, tanto de ferro gusa para fundição quanto de ferro batido para serralheria, pois a segunda metade do século XIX é o período em que, além do surgimento e crescimento das estradas de ferro, os gradis de ferro nas sacadas das janelas ganha grande popularidade, mercado e produção local $[31,32]$ apesar da boa disponibilidade de literatura sobre os altos fornos, da frequência com que caraterísticas técnicas dos altos fornos foram discutido nos relatórios, e apesar do número de brasileiros que discutiu publicamente o assunto, nada disso foi suficiente para empolgar empresários brasileiros a arriscar-se no negócio de produzir gusa a partir de minério de ferro, pelo menos até 1888.

Uma exceção foi o francês Jean de Monlevade (1791-1872), formado em 1812 no curso de Engenharia de Minas da École Polytechnique de Paris [33,34], que veio ao Brasil em 1817 e chegou a construir e operar um alto forno em Caeté, Minas Gerais, entre 1818 e 1823, fundindo bigornas, aguilhões, almofarizes e vasos. Entretanto, preferiu investir, em 1824, na redução direta, iniciando outro empreendimento em 
São Miguel do Piracicaba, também em Minas, que durou até 1891. Não se conhece a existência de algum desenho do vazio interior de seu alto forno.

Outra exceção, também dirigida por um estrangeiro, foi um forno construído por uma empresa inglesa, a Mineração de Ouro do Gongo Soco, em Minas Gerais. Seu diretor, Sr Baird, construiu em 1828 um forno de 5 metros de altura, para produzir gusa para a mineradora. De acordo com uma nota no livro Pluto Brasiliensis [12], o minério de ferro brasileiro foi analisado em Londres, pelo Mr. Faraday. É provável que se trate do famoso químico e físico londrino, que naquele momento trabalhava na Royal Institution. O forno, entretanto, não produziu gusa (como era de se esperar, para um forno tão baixo). Segundo o relatório da diretoria da empresa, ele foi adaptado para produzir ferro por redução direta [12]. Seus remanescentes ainda podem ser vistos na localidade de Gongo Soco.

Uma terceira aventura privada, desta vez bem sucedida, surgiu mais tarde, numa associação entre capitalistas brasileiros e um siderurgista suíço radicado na França. Um aluno da Escola de Minas de Ouro Preto, Augusto Barbosa da Silva, foi para a França numa viagem-prêmio e conheceu um siderurgista suíço, Albert Gerspacher, que trabalhava na usina francesa $D^{\prime}$ Audincourt. $O$ suíço foi convencido das oportunidades siderúrgicas de Minas Gerais e para cá veio, com filha e filho, em 1887. Articulando-se com dois engenheiros da Estrada de Ferro D. Pedro II (Amaro da Silveira e Henrique Hargreaves) e com o empresário gaúcho Carlos G. Da Costa Wigg, investiram 100 contos de réis na criação da empresa Gerspacher e Amaro que tinha por objetivo fornecer gusa para as fundições brasileiras. Iniciam em 1888 a construção de um alto forno com a mesma altura dos fornos gêmeos de Ipanema, 8 metros [35], mas com capacidade nominal muito maior, produção de 5 toneladas diárias, em Itabirito, Minas Gerais, para operar com carvão vegetal. O ângulo da rampa é bem mais íngreme que o dos fornos de Ipanema e o diâmetro da goela é muito maior, como mostra a figura 11, retirada de um caderno de notas de José Gerspacher [35]. Além disso, a figura 11 mostra no topo a principal inovação, o préaquecimento do ar. O empreendimento prossegue mesmo com a morte de Albert Gerspacher em 1889, sucedido por seu filho Joseph Gerspacher. Em 21 de julho de 1891 correu o primeiro gusa na Usina Esperança.

Uma bolha de crescimento econômico nacional no início da década de 1890 , provocada por crédito excessivo iniciado logo após a abolição dos escravos [36] resultou na formação da Cia Nacional de Forjas e Estaleiros [37] em 1891, a partir do Estaleiro e Fundição de Ponta de Areia (Mauá) que tinha por diretores Antonio Augusto Fernandes Pinheiro, Manoel Buarque de Macedo, Carlos Conrado de Niemeyer e Duarte Huet Bacellar Pinto Guedes. Em 1892 essa empresa comprou a Usina Esperança e logo depois comprou a Usina Monlevade, que ainda operava fornos de redução direta. Em 1900, a Usina foi comprada pelo engenheiro Joaquim José de Queiroz Junior, que a manteve em operação por décadas [37]. Remanescentes do alto forno representado na figura 11 podem ser vistos na entrada da cidade de Itabirito.

José Gerspacher construiu e/ou colocou em operação outros oito altos fornos, entre 1920 e 1938. Seu caderno de notas registra o perfil de todos eles [35]. Essa evolução é a realização do sonho do José Vieira Couto (1752-1827), que em 1799 
afirmou que o caminho para o Brasil deveria ser o de "produzir ferro em grande" [38], com altos fornos.

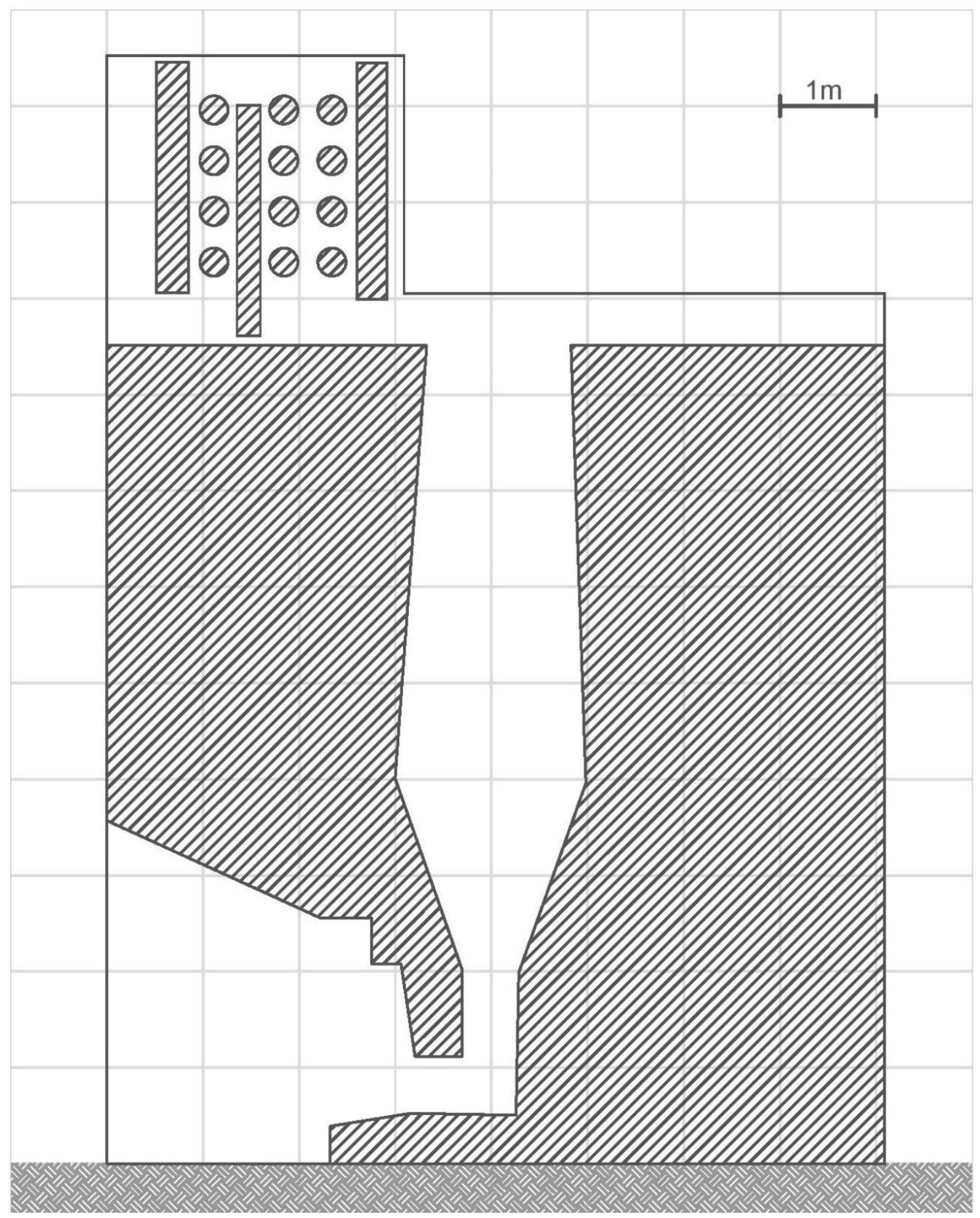

Figura 11. Desenho de perfil do primeiro alto forno construído na Usina Esperança, em Itabirito, Minas Gerais [35].

\section{0 perfil do alto forno número 1 da CSN}


O último vazio interior que aqui se apresenta, na figura 12, é o corte do alto forno número 1 da CSN [39], que produziu o primeiro gusa em 1946. Seu perfil, de 25 metros de altura e diâmetro de cadinho de 7,6 metros, era parte do projeto siderúrgico concebido pela empresa americana Arthur G. McKee, que já tinha projetado várias instalações, inclusive a usina de Magnitogorsk, na União Soviética. O grupo de engenheiros reunido em torno de Edmundo de Macedo Soares (19011989) tinha feito o projeto conceitual, o estudo de viabilidade econômica e a negociação financeira. O engenheiro Renato Azevedo (1916-2013) foi encarregado de acompanhar o projeto do alto forno na McKee, em Cleveland, EUA, e depois sua construção em Volta Redonda [40]. O projeto do alto forno foi praticamente idêntico ao projetado pela McKee para a Inland Steel, em East Chicago, estado de Indiana, EUA. O ângulo da rampa, no projeto original, foi de $82^{\circ} 28^{\prime} 29^{\prime \prime}$, e esse ângulo foi mantido nas 3 primeiras reformas. Renato Azevedo acompanhou os técnicos da McKee que vieram instalar e operar o alto forno, até que em 1954 ele assumiu a sua operação.

\section{Comentários Finais}

No mundo todo, o século XIX é um período de intensa experimentação tecnológica, no enfrentamento de problemas e na busca empírica de soluções. O perfil do vazio interior do alto forno é um desses campos de experimentação. Não era um objeto de estudos fácil de ser tratado, pois cada novo perfil tinha que ser testado durante anos, e muitas outras variáveis afetavam os resultados dos indicadores de desempenho. Ainda assim, os engenheiros de Ipanema experimentaram, buscando na literatura e em consultores internacionais o melhor caminho para o aumento da produtividade do forno, na busca da viabilidade econômica do empreendimento. É necessário romper com a tradição dos comentadores da história da siderurgia no Brasil, que tratam a Fábrica como a história de um fracasso, saltando das fofocas anti-suecos na primeira diretoria para a exigência pública de fechamento da Fábrica, feita por Pandiá Calógeras em 1895. Poucos perceberam aquilo que o professor Nestor Goulart dos Reis reconheceu: Ipanema é "o núcleo mais importante de desenvolvimento de tecnologia em São Paulo, antes das ferrovias." Um grande volume de material sobre a Fábrica resta a ser recuperado, nos arquivos nacionais e de São Paulo. Do ponto de vista da história da engenharia, é um privilégio dispor de uma documentação tão farta sobre a evolução técnica, administrativa e política da Fábrica de Ferro de Ipanema.

\section{Agradecimentos}

Ao CNPq pela bolsa do primeiro autor e ao programa de Ensino \& História de Ciências da Terra pelo auxilio na pesquisa ao Arquivo Nacional, no Rio de Janeiro, pelo Projeto Universal e Bolsa de Produtividade do último autor, à Fapesp pelo Projeto de Pesquisa do prof. Zuffo.

Ao professor Antonio Barossi, que viabilizou o contato com a equipe italiana, e ao professor Antonio Brito da Cruz, que sugeriu o contato com o CITI da USP. 


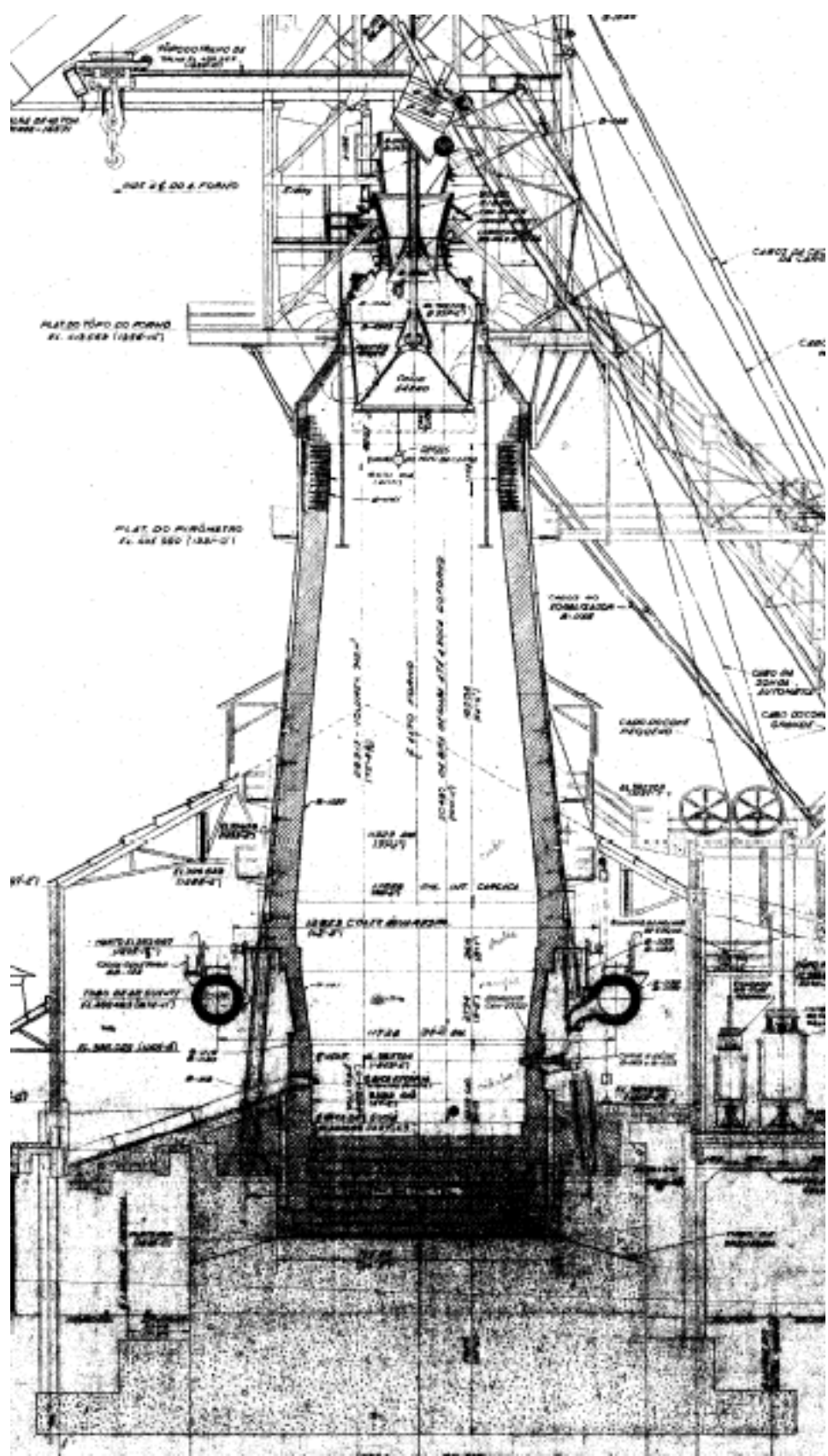

Figura 12. Perfil do alto forno número 1 da CSN

\section{REFERÊNCIAS}

1 Telles, Pedro da Silva, História da Engenharia no Brasil: séculos XVI a XIX. Rio de Janeiro: Ed Livros Técnicos e Científicos; 1983

2 Reis, Nestor Goulart, Dois Séculos de Projetos em São Paulo - Grandes Obras e Urbanização - 1800-2000. São Paulo: EDUSP, 2010. 250p.

3 Calógeras, JP A Fábrica de Ferro de S. João de Ipanema. Revista Brazileira, ano 1, tomo 1,p. 83-95, p. 179-186, p. 290-300, tomo 2, p. 90-100, p. 212-227, 1895.

4 Monteiro Lobato, J. Ferro. São paulo: Cia Editora Nacional; 1931.

5 Landgraf, FJG. Ferrando o Brasil. In: Marisa Lajolo. (Org.). Monteiro Lobato livro a livro Obra adulta. São Paulo: Ed. UNESP; 2014. p. 235-246. 
Caldeira, J. Mauá, Empresário do Império. São Paulo: Ed. Companhia das Letras; 1995. 557 p.

7 Souto Maior, PM. Nos caminhos do ferro - Construções e manufaturas no Recife (1830-1920). Recife: CEPE, 2010. 277p.

8 Landgraf, FJG Araújo PEM Schroeder R. Ipanema e os alemães. In: Kupfer, E. E. et al.. (Org.). Martius-Staden-Jahrbuch. 1ed.São Leopoldo: Oikos, 2016, v. , p. 164-177.

9 Arsenal usando gusa de Ipanema.

10 Geerdes M Chaigneau R Kurunov I Lingiardi O Ricketts J. Modern Blast Furnace Ironmaking: an introduction. Amsterdam: IOS Press; 2015.

11 Guimarães, PE. As Minas portuguesas do antigo regime ao liberalismo. Arqueologia \& Indústria. 1999-2000. P.53 a 80.

12 Eschwege W L. Pluto brasiliensis. Berlin: G. Heimer; 1883. Tradução: Belo Horizonte/São Paulo: Itatiaia/Ed. USP, 1979.

13 Moraes, FAP. Subsidios para a historia do Ypanema. Lisboa: Imprensa Nacional, 1858. Ed. Fac-símile. Sorocaba: Ottoni Editora; 2010.

14 Dupre, L. Memória sobre a Fábrica de Ferro de São João de Ipanema. Annaes da Escola de Minas de Ouro Preto, número 4, pag 37-68, 1885.

15 Landgraf, FJG O engenheiro metalurgista José Bonifácio. In: C A L Filgueiras; G M de Lima; E N dos Santos; L A Montoro. (Org.). Simpósio Comemorativo Vicente Coelho de Seabra. 1ed.Belo Horizonte: UFMG, 2015, v. 1, p. 173-190.

16 Andrada e Silva, JB. Memória econômica e metalúrgica sobre a Fábrica de Ferro de Ypanema, 1820. Publicada por Barbosa, FA. Dom João VI e a siderurgia no Brasil. Rio de janeiro: Biblioteca do Exército; 1958.

17 Landgraf, FJG Araujo PEM. A arquitetura do alto-forno e a biblioteca perdida de Ipanema: técnica e conhecimento no Brasil Joanino. In: SEMINÁRIO NACIONAL DE HISTÓRIA DA CIÊNCIA E DA TECNOLOGIA, 14.,, 2014, Belo Horizonte. Anais Eletrônicos. São Paulo: SBHC, 2015. p. 1-15. http://www.14snhct.sbhc.org.br/conteudo/view?ID_CONTEUDO=800

18 Sporback, S.-V. Carl Gustaf Hedberg 1774-1827 Haraker-Hagelsrum- Ipanema-Rio de Janeiro.

19 Karsten C Handbuch der Eisenhüttenkunde, 2 vols, Berlin: ;1816.

20 Hassenfratz, Jean-Henri. La Sidérotechnie, ou l'art de traiter les minéraux de fer, pour en obtenir de la fonte, du fer et de l'acier. Paris: Firmin Didot, tome premier, 1812.

Disponível em: http://bavarica.digitale-sammlungen.de

21 Capanema, G. Schuch. Diário do Rio de Janeiro, 1863

22 Jardim, Relatório ao Ministério da Guerra, de 7/02/1849.

23 Petrone, MT. A lavoura canavieira em São Paulo - expansão e declínio 1765 - 1851) São Paulo: Difel; 1968.

24 Capanema

25 Santos, NP. A fábrica de ferro São João de Ipanema: economia e política nas últimas décadas do Segundo Reinado (1860-1889). 180 p. Dissertação (Mestrado em

História Econômica) - Faculdade de Filosofia, Letras e Ciências Humanas da Universidade de São Paulo. São Paulo, 2009.

26 Mursa JS. Relatório ao Ministro da Guerra, fevereiro 1867. APESP: CO5216 1867_0311

27 Le Coze. J. Histoire de fontes.Les descriptions du XVIIle siècle. Partie I: Sur la producion des fontes. C.R. Chemie 11 (2008) 1289-1300.

28 Mursa relatório 1875

29 Anônimo. Visita do imperador à Ipanema. Revista de engenharia, 1886.

30 Sidow A. Jornal A Província de S. Paulo, edição de 17.06.1882.

31 Kühl, Beatriz Mugayar. Arquitetura do Ferro e arquitetura ferroviária em São Paulo. São Paulo: Ateliê Editorial:Fapesp:Secretaria da Cultura, 1998. 436 p.

32 Costa, Cacilda Teixeira da. O sonho e a técnica - arquitetura do ferro no Brasil. São Paulo, Edusp 1994. 198 p. 
33 Pessoa, J. M. do Nascimento. Monlevade, Vida e Obra. Belo Horizonte: Minas Gráfica. 1973. 158p.

34 Câmara, José de Sá Bittencourt. Memória Mineralógica do Terreno Mineiro da Comarca de Sabará (1825). Revista do Arquivo Público Mineiro. Ouro Preto: Imprensa Oficial de Minas Gerais, ano II, fascículo 4, p. 599-609, out./dez. 1897.

35 Gerspacher, José. Notas sobre usinas siderúrgicas. 1939. Caderno da biblioteca particular de Renato Azevedo Filho, Volta Redonda.

36 Carvalho, JM. A construção da Ordem. Teatro de Sombras. 5ª Edição. Rio de Janeiro: Ed. Civilização Brasileira; $2010 \ldots 459$ p.

37 Alfonso-Goldfarb AM Nascimento CAR Ferraz MHM. Um estudo sobre a implantação da moderna siderurgia no Brasil: o caso da Usina Queiroz Júnior. Revista da SBHC n.10, p.3-12, 1993.

38 Vieira Couto, José. Memória sobre a Capitania das Minas Gerais (1799). Ed. Fundação João Pinheiro, estudo crítico de Júnia Ferreira Furtado. 1994. 104p.

39 XXX, a fonte do desenho do AF1 da CSN.

40 Moreira, Regina da Luz. CSN - Um sonho feito de aço e ousadia. Rio de Janeiro, Edição Fundação CSN, CPDOC da FGV e larte, 2000, 191p.. 
